\title{
Factors affecting innovation capacity in Vietnamese Southern high technology industries
}

\author{
DOAN THI HONG VAN \\ University of Economics HCMC - hongvan@ueh.edu.vn \\ BUI NHAT LE UYEN \\ HCMC University of Technology - lephuonghauyen@gmail.com
}

\begin{abstract}
ARTICLE INFO ABSTRACT
Article history:

Received:

July, 28, 2016

Received in revised form:

Apr., 21, 2017

Accepted:

June, 30, 2017

Keywords:

Innovation

Numerous studies have demonstrated that the success of businesses in the era of knowledge-based economy depends on their innovation capacity (Azevedo et al., 2007). Therefore, the main goal of this study is to explore the factors that impact the innovation capacity of enterprises in the Vietnam Southern high tech industry. Besides the qualitative method, the study carries out a survey of 380 enterprises in the fields of electronics, microelectronics, information technology, telecommunications, precision engineering, automation, biotechnology, and nanotechnology. The results reveal that total quality management, internal human resources, absorptive capacity, government support, and collaboration networks impact positively on the innovation capacity. In addition, the research proposes solutions for high tech enterprises to boost their innovation capacity in the future.
\end{abstract}

Total quality

management

Human resources

Absorbtive capacity

Collaboration networks

High-tech industry 


\section{Introduction}

During two decades of the $80 \mathrm{~s}$ and $90 \mathrm{~s}$ of the 21 st century and then, the basic theory of innovation from the previous generation has inspired many researchers to explore and gradually perfect the concept of innovation capacity. Suarez-Villa (1990) suggested that if the innovation capacity of a country/region or a geographic area develops quickly, it can attract more highly skilled and experienced labor, promote the growth of income and trade in the area, whereas if the level of innovation capacity declines, it will be faced with difficulties and depression in the future (Suarez, 1990). Innovation capacity holds the key to resolve many urgent challenges in finding solutions to increase productivity and improve the quality of products; it is the origin of all invention, creativity, and new technologies (Prajogo \& Ahmed, 2006; Ameseder et al., 2008; Gellynck et al., 2007; Ritter \& Gemu“nden, 2003; Roy et al., 2004).

In parallel, high-tech industry is one of the main fields, considered an inevitable trend for all economic growth activities in the future (Shanklin \& Ryans, 1984; Goldmanm, 1982; Riggs, 1983; Nystrom et al., 1990; Petrauskaite, 2009). It is also associated with the intensity of research and development (R\&D), including efforts driven by innovation and seeking differentiation to catch up the latest technology trend of competitors. According to Mohrman and Von Glinow (1986), hightech organizations are the ones operating in transformated environment restlessly. That is why high-tech industries innovate constantly (Goldmanm, 1982; Riggs, 1983; Shanklin \& Ryans, 1984; Nystrom, 1990; Maclnnis \& Helslop, 1990). Thus, promoting innovation capacity has become a challenging strategy for the enterprises that operate in the high-tech environment.

Actually, innovation capacity has constantly improved in the methodology, approaches, or new perspectives in the world. Since then, the relationship between innovation capacity and a number of factors, such as total quality management, organizational learning, government support, cooperation networks, absorptive capacity, internal human resources, patent management, internationalization, lean management, and so forth, have been gradually discovered.

However, there are still research gaps. For example, Tidd et al. (1997) demonstrated that total quality management (TQM) impacts negatively on innovation activities because TQM aims at optimizing costs, but innovation needs to promote investment, while other scholars recognized the important role of TQM (Kanji, 1996; Gustafson \& Hundt, 1995, Kang \& Park, 2011). Typically, they explored TQM through the creation of a system to organize and promote innovation culture and the principles of TQM, such as customer orientation, leadership, continuous improvement, focus on quality, etc., which are the factors for success of the innovation process. In this study there is a need to clarify how the role of TQM in promoting innovation capacity can be confirmed.

In addition, a majority of studies 
measured the government support through participation in R\&D projects sponsored by the government (Almus \& Czarnitzki, 2003; Feldman \& Kelley, 2006; Kang \& Park, 2011). In developing countries such as Vietnam, nonetheless, only potential or large businesses and institutions specializing in doing scientific research are eligible to be entitled to these projects, also called formal cooperation. While Vietnam's high-tech industry is characterized by small- and medium-sized enterprises as well as a lack of development resources, these firms have few opportunities to access government's $\mathrm{R} \& \mathrm{D}$ projects. So, is the government's contribution to the innovation activities of enterprises also reflected in many different aspects as were identified by Wallsten (2000), Beugelsdijk and Cornet (2002), Romijn and Albaladejo (2002), Souitaris (2002), Dieu Minh (2010)? This study will accordingly combine qualitative and quantitative approaches to add new observable variables to the scale of government support.

For the concept of internal human resources, Bantel and Jackson (1989) confirmed that the innovation success of an organization is managed by highqualification human resources. In contrast, De Clercq and Dakhli (2004) argued that the ability of accumulating experienced work over time would create important skills for individuals rather than qualification for themselves. Thus, we have strong motivation in finding the suitable scale for government support and internal human resources.

Moreover, in Asia a remarkable research model of Kang and Park (2011) has demonstrated that many enterprises access external network to get the resources that they lack or reduce the risks related to the innovation efforts. This interaction, in fact, helps enterprises overcome the shortcomings of information and scientific knowledge. Kang and Park (2011) also verified the positive effect of collaboration network on innovation capability, which was similarly concluded by many other researchers (Geroski, 1990; De Propis, 2002; Freel \& Harrison, 2006; Oerlemans et al., 2006; Tomlinson, 2010).

Indeed, knowledge property is recognized as an important factor for businesses' innovation activities, stemming from learning effort or organizational learning. Organizational learning is one of the main resources to produce knowledge for innovation activities because innovation often originates from research and development (R\&D) as well as from other types of business (Argyris \& Schon, 1978; Bontis et al., 2002; Nonaka \& Takeuchi, 1995; Davenport \& Prusak, 1998; Rothaermel \& Deeds, 2004; Hung et al., 2010). Given the corporate culture with a focus on learning, when people work and share information together, this will nourish and sustain the knowledge creation system that facilitates businesses' innovation activities (Mansfield, 1983).

However, if firms long to manage and operate external knowledge resources, they need to have the capacity to absorb (absorptive capacity). Jantunen (2005) approached absorptive capacity via three levels: knowledge acquisition, knowledge 
dissemination, and knowledge utilization, which means that absorptive capacity is a sequential process. Jantunen (2005) proved that firms increase innovation to gain competitive advantage by accumulating absorptive capacity.

In brief, the research gaps identified via the litterature review and practical context have shown that an investigation into specific factors affecting the innovation capacity of businesses in Vietnam's southern high-tech industry is imperative, particularly when Vietnam integrates into the international economy with Asean Economic Community accession and when high technology is expected to be one of the core economic fields (National Programs for Developing High Technology to 2020). Therefore, this study has three main goals, which are: (i) to determine the relationships between TQM, internal human resources, absorptive capacity, government support, collaboration network, organizational learning, and innovation capacity; (ii) to make some adjustments, additional exploration of some controversial measurement scales such as the concept of government support and internal human resources; and (iii) to propose solutions to boosting innovation capacity for domestic high-tech businesses.

\section{Theoretical basis and research model}

\subsection{Innovation capacity}

Higgins (1995) argued that an organization can only survive and prosper in the 21 st century if it enhances innovation capacity and has strategic actions to improve it. Since then the importance of innovation capacity has been widely studied and become the foundation for subsequent academic research (Kang \& Park, 2011; Alpkan et al., 2010; Chen \& Taylor, 2009; Lee \& Wong, 2009; Block \& Keller, 2008; Liu \& Buck, 2007; Giuliani \& Bell, 2005; Beugelsdijk \& Cornet, 2002). In 1997 George Papaconstantinou, an OECD's economic consultant, stated that the innovation capacity of an organization depends on the efforts to create new products or improve manufactured process. It is also affected by the level of human resources and the ability to learn and accumulate knowledge (Papaconstantinou, 1997). According to Szeto (2000), innovation capaciy is the continuous improvement of capabilities and resources owned by enterprises to explore and exploit opportunities for developing new products to meet market needs. From the same perspective, Lawson and Samson (2001) concluded that innovation capacity is the ability to convert knowledge and ideas into a product/process or a new system for firms' benefits.

\subsection{Total quality management (TQM)}

It has been proven that TQM is a useful administrative solution to innovation and improvement in a business's competitive advantage (Bolwijn \& Kumpe, 1990; Hamel \& Prahalad, 1994; Martinez-Costa \& Jimenez-Jimenez, 2008; McAdam \& Armstrong, 2001; Prajogo \& Sohal, 2003). Furthermore, if an organization is 
committed to incorporating the principles of TQM into its operating systems, the innovation efforts will bring expected results (Mahesh, 1993; Dean \& Evans, 1994; Kanji, 1996; Tang, 1998; Roffe, 1999). This observation was also approved by Barrow (1993) and Conner and Prahalad (1996). Watkins and Marsick (1993) pointed out that the main function of TQM is to create an organizational culture that appreciates personal goals; it also helps improve the quality, transfer knowledge, and stimulate innovation capacity.

Although there are many principles of TQM, this study analyzes four. First, customer-oriented principle encourages organizations to know the customer's needs and desires, thereby intending to develop and introduce new products (Juran, 1998; Prajogo \& Sohal, 2003; Hung et al., 2010. Second, the principle of continuous improvement facilitates application of innovative thinking and continuous changes to adapt to operating environment (Prajogo $\&$ Sohal, 2003; Hung et al., 2010). Third, for the employee involvement principle, increasing autonomy for workforce means developing innovative behavior (Amabile \& Grykiewicz, 1989; Spreitzer, 1995; Prajogo \& Sohal, 2003; Hung et al., 2010). Forth, top management support refers to collaborative relationships between managers and employees within an organization; top managers encourage an environment of trust and mutual sharing, which creates successful innovation (Hung et al., 2010). Thus, from this point of view this study agrees that TQM contributes to enhanced innovation capacity.
H1: TQM positvely affects the innovation capacity of businesses in Vietnamese southern high-tech industries (+).

\subsection{Organizational learning}

Many studies provided evidence that organizational learning has a major role in promoting innovation at three levels: individual, group, and business (Egan \& Bartlett, 2004; Ellinger \& Howto, 2002). Rothaermel and Deeds (2004) found that learning in a business organization is aimed at creating mutual trust and business culture in which exchanging and sharing knowledge between members of the organization is promoted, which will positively influence the development of new products and general innovation efficiency. Additionally, many researchers emphasize that organizational learning improves revenue, profit growth, and customer satisfaction, facilitating achievement of innovative results (Davenport \& Prusak, 1998; Wang et al., 2007). Thus, companies develop new products by creating organizational value in learning and encouraging employees to collect market data and then to share or use them for innovation purpose (Wang et al., 2007).

This study measures organizational learning through the following two components: (i) learning culture, which allows employees to work together and toward collaborative relationships, share knowledge in the learning process, and apply that knowledge to produce new products and process; and (ii) learning strategy: developing a learning culture 
requires establishing a strategy with clear objectives, and that strategy must be driven by a culture that encourages learning and interchange. A good learning strategy will create new ideas (Davenport \& Prusak, 1998), and a dynamic and studious environment is always looking for creativity.

Therefore, it is expected that organizational learning impacts positively on innovation capacity of businesses in high-tech industries.

H2: Organizational learning positively affects the innovation capacity of businesses in Vietnamese southern high-tech industries $(+)$.

\subsection{Government support}

The concept of government support stems from the basic theory suggested by National Innovation System (NIS), which is an interactive system of private enterprises, universities, scientific institutions, and the government. The system produces science and technology within national borders, in which the government holds an important role (Niosi et al., 1993). Thus, the government not only acts as an investor and gives financial support for the research and development of the enterprises, but also promotes innovation capacity by regulating supported mechanisms such as subsidies, tax incentives, loans, or R\&D human resources (Wallsten, 2000; Beugelsdijk \& Cornet, 2002; Romijn \& Albaladejo, 2002; Souitaris, 2002; Park, 2006; Kang \& Park, 2011).

According to Kang and Park (2011), the government policy on supporting $R \& D$ projects related to financial investment and human capital becomes indispensable for innovation activities. Feldman and Kelley (2006) also demonstrated the important role of government in stimulating innovation and economic growth by supporting potential R\&D projects to achieve high profits. From these arguments for the cruciality of the government's role, we propose the next hypothesis:

H3: Government support positively affects the innovation capacity of businesses in Vietnamese southern high-tech industries (+).

\subsection{Collaboration network}

Tether (2002) emphasized that the collaboration in the value chain is a prerequisite for transferring knowledge and technical know-how. Cooperation also contributes to setting up standard in the industry as well as improving the application of new techniques. Actually, there are many empirical investigations demonstrating the close relationship between businesses' innovation capacity and the value chain interaction (Baum et al., 2000; Belussi et al., 2010; George et al., 2002; Hagedoorn, 1993; Romijn \& Albaladejo, 2002; Rothaermel \& Deeds, 2006; Shan et al., 1994; Kang \& Park, 2011). According to Kang and Park (2011), a collaboration network should be categorized into two kinds: upstream and downstream. Upstream collaboration is the linkage between enterprises and universities or research institutions. Downstream collaboration refers to the connection of 
businesses in the same field. Therefore, we absolutely confirm the positive relationship between collaboration network and innovation capacity.

H4: Collaboration network positively affects the innovation capacity of businesses in Vietnamese southern high-tech industries (+).

\subsection{Absorptive capacity}

Schumpeter's (1911) innovation theory is a cornerstone for formating many famous concepts in experimental studies, including absorptive capacity.

Many studies have demonstrated that absorptive capacity is an essential factor affecting technological innovation capabilities (Cohen \& Levinthal, 1990; Dosi, 1988; Nelson \& Winter, 1982; Giuliani \& Bell, 2005). In other words, absorptive capacity refers to the ability of a business to develop or improve its new products through the adaptation and application of external sources of knowledge (Cohen \& Levinthal, 1990). Therefore, the higher the absorptive capacity, the more it promotes $R \& D$ capability and then increases innovation performance. However, absorptive capacity is a predictor index, so businesses will have capacity to absorb, assimilate, and use knowledge for innovation activities in totally different manners. Thus, only when a business achieves a certain absorptive capacity does it have opportunities to take advantage of external technology sources.

According to Lichtenthaler (2009), "absorptive capacity is the ability of an enterprise to use external sources of knowledge through a sequential process of exploration, transformation, and exploitation." Also, in this study we inherit Jantunen's (2005) technique by assessing absorptive capacity through three components: knowledge acquisition, knowledge dissemination, and knowledge utilization. Accordingly:

H5: Absorptive capacity positively affects the innovation capacity of businesses in Vietnamese southern high-tech industries (+).

\subsection{Internal human resources}

Empirical evidence has consistently demonstrated the relationship between human capital and innovation capacity. Typically, Bantel and Jackson (1989) revealed that behind the success of an organization, its operation process is commonly managed by knowledgeable and expert personnel. Alternatively, Anker (2006) maintained that cultivating the skills and knowledge of employees will increase innovation capabilities. On the other hand, human resources are precious; accumulating knowledge and capacity promotes the role of coordinated efforts to adapt oneself to the market, enhance innovation, and improve organizational performance (Hayton \& Kelley, 2006). Also, Alpkan et al. (2010) suggested that the origin of all ideas or creativity comes from human thinking and experience, so professional human resources is the start for any innovation process, symbolizing learning and absorbing knowledge selectively. In contrast, uneven 
and restricted levels of knowledge absorbed by human resources will lead to decreased managerial ability and knowledge transference, which is fundamental to innovation activities. From this point of view, we expect that an organization's innovation capacity is likely to be fueled if it possesses quality workforce, having a good educational background and professional skills along with great flexibility and ability to handle different assigned tasks.

H6: Internal human resources positively affect the innovation capacity of businesses in Vietnamese southern high-tech industries $(+)$.

\subsection{Proposed research model}

This study inherits the research model of Jantunen (2005), Hung et al. (2010), and Kang and Park (2011). From the arguments for the research gaps presented in the previous section (Introduction), we employ qualitative research to explore new observable variables for the two concepts: government support and internal human resources. The study proposes a theoretical model, which consists of one dependent variable and six independent variables, comprising total quality management (TQM), organizational learning, government support, absorptive capacity, internal human resources, and collaboration network, corresponding to the six hypotheses as formulated.

\section{Research methodology}

\subsection{Research methodology}

The study used mixed methods, including qualitative research and quantitative research to adjust, supplement, modify, and test the research scales as well as the research model and hypotheses:

Qualitative research was conducted using in-depth interview and focus group discussion in order to adjust the content of observable variables to suit the characteristics of Vietnamese businesses in high-tech industries and to explore new observable variables for the concepts that have controversial scales (government support and internal human resources). 


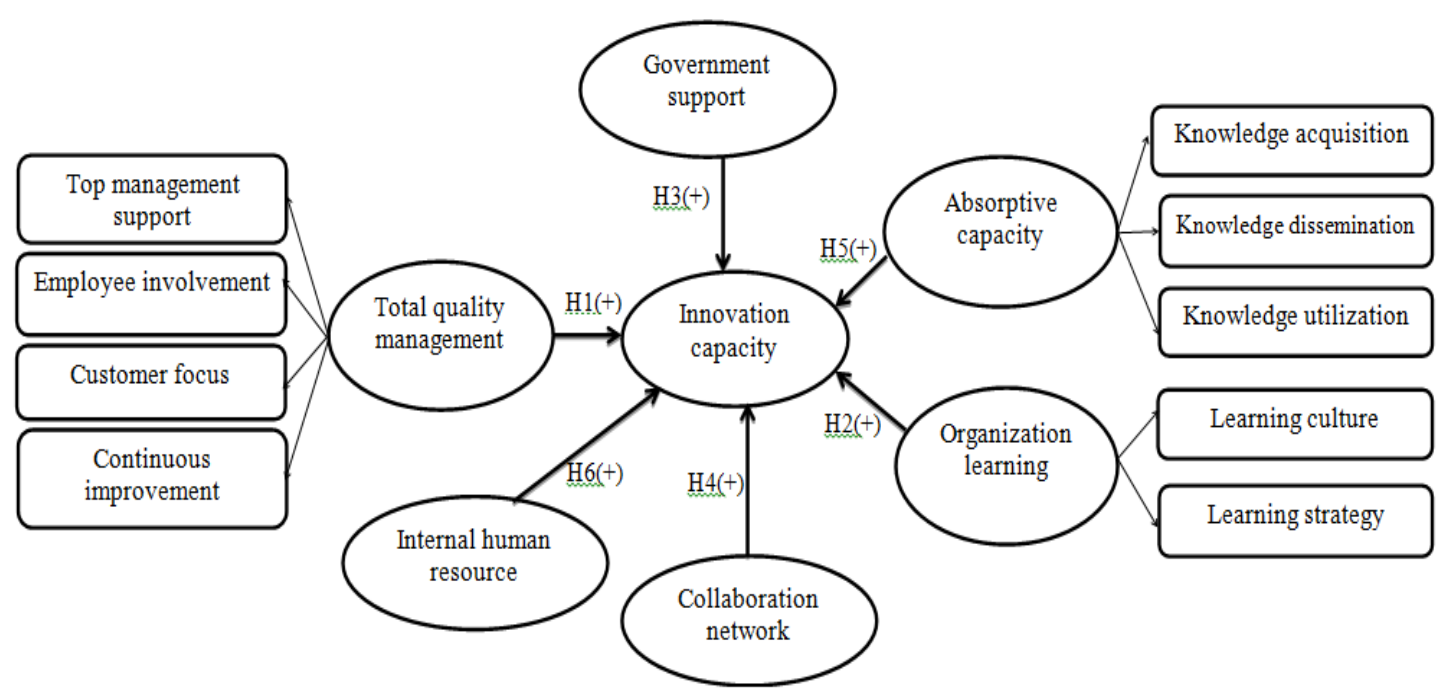

Figure 1. Theoretical model of factors affecting innovation capacity of businesses in high-tech industries

In-depth interview was carried out with five experts who are extensive experienced researchers in Vietnamese southern hightech industries. All of them affirm the significant effects of total quality management (TQM), organizational learning, government support, absorptive capacity, internal human resources, and collaboration network on innovation capacity. In this research stage we explored and collected as much information as expected on the research topic, especially the concepts needed to rebuild the scales. Based on that we could adjust or supplement new observable variables from the original scales to build the first-draft ones.

Focus group discussion was held with a total of eight managers having a fine grasp of their firms' development process and determinate innovation capability as an indispensable objective. At this stage the main objective was to assess the first-draft scales' content and build the second-draft ones for quantitative research during the next stages. We adopted focus group method because it is suitable for information exploitation and exchange of views among group members, showing the opposition and similarity in discussion to realize the latent aspects of the research.

First, many researchers debated how to measure innovation capacity in the best way (Kanji, 1996; Prajogo \& Sohal, 2003; Tang, 1998). The OECD countries measured innovation capacity through $R \& D$ expenditures or patent (OECD, 1997b; Bransetter \& Sakakibara, 2002; Czarnitzki et al., 2007). Liu and Buck (2007) used the scale of new product per employee to measure innovation capacity. However, in developing countries innovation is not necessarily derived from the results of $R \& D$, 
but can come from the daily growth of businesses, or from the collaboration with clients or optimization processes (HirschKreinsen, 2008). The result of qualitative research confirmed that innovation capacity should be clearly quantified by counting the number of a business's innovation in a certain period, namely three years from 2012 to 2014. Thus, the scale of innovation capacity (IC) includes five observable variables and only emphasizes product innovation and process innovation.

Second, this study applies the scale of Coyle-Shapiro (2002) to measure TQM. This concept is described by 16 observable variables, and consists of four components: top management support (TQMTM), employee involvement (TQMEI), continuous improvement (TQMCI), and customer focus (TQMCF), each of which has four observable variables.

We also use the scale of Rhodes et al. (2008) to measure organizational learning (OL), defined by nine observable variables. This concept consists of two components: learning culture (OLLC), which has five statements and learning strategy (OLLS), which has four statements.

In addition, Wallsten (2000) built the scale of government support. Firstly, the author measured the ability of an enterprise to access potential $R \& D$ projects sponsored by the government. In this study, we also adopt his proposed scale to measure government support (GS). Besides, qualitative research has explored two new observable variables for the original scale: (i) the ability to access preferential loans; and (ii) the government facilitation of professional human resources training and development.

Furthermore, this study applies the scale of Kang and Park (2011) to measure collaboration network (CN), covering domestic upstream cooperation, international upstream cooperation, domestic downstream cooperation, and international downstream cooperation. Upstream collaboration refers to linkages between enterprises and universities or research institutions. Downstream collaboration depicts the relationship between the companies in the same field. Thus, the scale of collaboration network has four observable variables.

For measuring the absorptive capacity (AC), moreover, we employ the scale of Jantunen (2005). This concept is assessed through three components: knowledge acquisition (ACKA), knowledge dissemination (ACKD), and knowledge utilization (ACKU). The scale is described by 16 observable variables, including four for knowledge acquisition, five for knowledge dissemination, and seven for knowledge utilization.

Last, to measure internal human resources this study uses the scale of Subramaniam and Youndt (2005), containing observable variables with a focus on three important elements such as skills, knowledge, and qualifications. Additionally, in-depth interview results argue that internal human resources are trained and practiced in a professional environment where they can gain access to new technologies, which makes them easily adapt to or well receive technological transfer, and invent the next 
generation of technology. Therefore, added to this study are two new observable variables, such as adaptability and responsibility. Thus, there are seven observable variables for the scale of internal human resources.

Quantitative research was conducted via two main phases: preliminary research with a sample of 89 enterprises to assess the concept scales and official research with a sample of 380 enterprises to test the research model and hypotheses. The data were cleaned and processed using SPSS20 and Amos20, along with Cronbach's alpha, exploratory factor analysis (EFA), confirmatory factor analysis (CFA), and structural equation modelling (SEM).

\subsection{Research data}

\subsubsection{Data collection}

In preliminary research (89 enterprises), after eliminating invalid ones from a total of 60 observable variables of the second-draft scale, the study has only 38 (the official scale). Therefore, the minimum sample size in the official quantitative phase determined based on Hair et al. (2006) is $\mathrm{n}=380$ (10x38). However, to further exclude invalid ones (no response provided or insufficient information), the study conducted a survey of 400 enterprises.

Survey respondents were senior managers of high-tech businesses in southern Vietnam, including Hochiminh City, Dong Nai Province, Binh Duong Province, and Vung Tau City in the industries such as information technology and communication, pharmaceuticals, biotechnology, nanotechnology, energy, mechatronics, automation, microelectronics, and high-tech services. These managers, directly in charge of the business plans, research and development (R\&D), and marketing, deeply understand their developing capacity, engage in strategic planning, and implement annual potential technological projects. They realize daily reality of their businesses and desire to enhance innovation capacity for sustainable growth.

The sampling process was conducted as follows. From the crowd $(\mathrm{N}=800)$, we calculated the hops $\mathrm{k}=\mathrm{N} / \mathrm{n}=800 / 400=2$, and selected the first sample unit between 1 and 2 using a random method (drawn). Then, the next sample unit was selected by adding $k$ to the first sample until obtaining the number of subjects th that need to be surveyed. In the case of the subject in the selected location that would not be interviewed, the next subject was choosen. The feasible form of the research was obtained by interview techniques through surveys (the official scale) after all respondents had been informed.

\subsubsection{Data description}

After elimination of invalid responses from the sample, the total sample size was 380 with the following characteristics:

- By sector: electronics and microelectronics (32.9\%), information technology and telecommunication (26.1\%), precision mechanics and automation (23.4\%), pharmaceuticals and biotechnology (7.6\%), nanotechnology and energy (4.5\%), and others, mainly high-tech services $(5.5 \%)$. 
- By ownership: domestic and foreignowed (equal in proportion-44.7\%), and joint venture (10.5\%).

\section{Results and discussion}

\subsection{Testing the concept's scales}

Testing the concept's scales is to ensure their reliability before more tests of the research model and hypotheses. In this stage the scales will be checked in terms of unidimesionality, reliability, convergent validity, and discriminant validity. Several testing methods to be adopted comprise exploratory factor analysis (EFA), Cronbach's alpha reliability, and confirmatory factor analysis (CFA).

4.1.1. Testing scales by EFA

The EFA results with Eigenvalue = 1.143 , the total variance extracted of $53.684 \%$ ( $>50 \%)$, KMO coefficient $=0.789$ $(>0.5)$ and Barlett's test with sig $=0.000$ $(<0.005)$ indicates that all sufficient conditions for EFA are ensured. Additionally, the factor loadings ranging from 0.542 to 0.885 are greater than 0.5 , and the differences of the factor loadings in each variable are greater than 0.3 , so the component scales are approved. There are 10 components extracted from the EFA results as reported in Table 1.

\section{Table 1}

EFA results

\begin{tabular}{|c|c|c|c|c|c|c|c|c|c|c|}
\hline \multirow{2}{*}{ Variables } & \multicolumn{10}{|c|}{ Components } \\
\hline & 1 & 2 & 3 & 4 & 5 & 6 & 7 & 8 & 9 & 10 \\
\hline TQMTM2 & .862 & & & & & & & & & \\
\hline TQMTM1 & .861 & & & & & & & & & \\
\hline TQMTM4 & .843 & & & & & & & & & \\
\hline TQMEI1 & .674 & & & & & & & & & -.244 \\
\hline TQMEI2 & .668 & & & & & & & & & \\
\hline TQMTM3 & .659 & & & & & & & & & \\
\hline TQMCI3 & & .885 & & & & & & & & \\
\hline TQMEI4 & & .859 & & & & & & & & \\
\hline TQMCI2 & & .832 & & & & & & & & \\
\hline TQMCI4 & & .796 & & & & & & & & \\
\hline IHC2 & & & .842 & & & & & & & \\
\hline IHC3 & & & .768 & & & & & & -.209 & \\
\hline
\end{tabular}




\begin{tabular}{|c|c|c|c|c|c|c|c|c|c|c|}
\hline \multirow{2}{*}{ Variables } & \multicolumn{10}{|c|}{ Components } \\
\hline & 1 & 2 & 3 & 4 & 5 & 6 & 7 & 8 & 9 & 10 \\
\hline IHC4 & & & .693 & & & & & & & \\
\hline $\mathrm{IHC} 1$ & & & .671 & & & & & & & \\
\hline IHC5 & & & .584 & & & & & & .231 & -.210 \\
\hline IHC6 & & & .542 & & & & & & .230 & \\
\hline TQMCF3 & & & & .787 & & & & & & \\
\hline TQMCF2 & & & & .669 & & & & & & \\
\hline TQMCF1 & & & & .626 & & & & & & \\
\hline TQMCF4 & & & & .585 & & & & & & \\
\hline ACKA2 & & & & & .878 & & & & & \\
\hline ACKA1 & & & & & .694 & & & & & \\
\hline ACKA3 & & & & & .652 & & & & & \\
\hline ACKD2 & & & & & & .796 & & & & \\
\hline ACKD1 & & & & & & .677 & & & & \\
\hline ACKD3 & & & & & & .609 & & & & \\
\hline GS3 & & & & & & & .742 & & & \\
\hline GS1 & & & & & & & .635 & & & \\
\hline GS2 & & & & & & & .617 & & & \\
\hline OLLS1 & & & & & & & & .658 & & \\
\hline OLLS2 & & & & & & & & .606 & & \\
\hline OLLC5 & & & & & & & & .592 & & .276 \\
\hline CN4 & & & & & & & & & .714 & \\
\hline $\mathrm{CN} 2$ & & & & & & & & & .579 & \\
\hline OLLC4 & & & & & & & & & & .695 \\
\hline OLLC3 & & & & & & & & & & .582 \\
\hline $\begin{array}{l}\text { Cronbach's } \\
\text { Alpha }\end{array}$ & .885 & .898 & .811 & .768 & .764 & .735 & .689 & .671 & .653 & .642 \\
\hline
\end{tabular}

For the scale of innovation capacity, the total variance extracted of $59.438 \%(>50 \%)$, EFA results with Eigenvalue $=3.219$, the and $\mathrm{KMO}$ coefficient $=0.842(>0.5)$ and 
Barlett's test with sig $=0.000(<0.005)$ satisfied, and there is one component suggest that EFA conditions are well extracted (Table 2).

\section{Table 2}

EFA results for innovation capacity scale

\begin{tabular}{lc}
\hline \multirow{2}{*}{ Variables } & Component \\
\cline { 2 - 2 } IC1 & 1 \\
IC2 & .917 \\
IC3 & .869 \\
IC4 & .747 \\
IC5 & .719 \\
\hline Cronbach's alpha & .540 \\
\hline
\end{tabular}

To ensure the reliability for these scales, the study tests the Cronbach's alpha for extracted components from EFA. The results show that the coefficients of $\alpha$ of all components are greater than 0.6 , and the corrected item-total correlations are greater than 0.3 .

The EFA's results in the official quantitative phase demonstrate 10 components with 36 observable variables (Table 3).

\section{Table 3}

Components in official research model

\begin{tabular}{|c|c|c|c|}
\hline Component & $\begin{array}{c}\text { Number of } \\
\text { observable } \\
\text { variables }\end{array}$ & $\begin{array}{c}\text { Observable } \\
\text { variables }\end{array}$ & Content value \\
\hline Component 1 & 6 & $\begin{array}{l}\text { TQMTM2 } \\
\text { TQMTM1 } \\
\text { TQMTM4 } \\
\text { TQMTM3 } \\
\text { TQMEI1 } \\
\text { TQMEI2 }\end{array}$ & $\begin{array}{l}\text { Component } 1 \text { mainly describes the efforts } \\
\text { made by business managers to promote } \\
\text { comprehensive innovation based on setting up } \\
\text { innovative strategies and creating an } \\
\text { interactive environment between top managers } \\
\text { and employees within their organizations. } \\
\text { This component is renamed "the support of top } \\
\text { managers" (TQMTM). }\end{array}$ \\
\hline
\end{tabular}




\begin{tabular}{|c|c|c|c|}
\hline Component & $\begin{array}{c}\text { Number of } \\
\text { observable } \\
\text { variables }\end{array}$ & $\begin{array}{c}\text { Observable } \\
\text { variables }\end{array}$ & Content value \\
\hline & & $\begin{array}{l}\text { TQMCI3 } \\
\text { TQMCI4 } \\
\text { TQMEI4 }\end{array}$ & $\begin{array}{l}\text { improve working methods to adapt to the } \\
\text { operating environment and minimize business } \\
\text { risks. } \\
\text { This component is renamed "continuous } \\
\text { improvement" (TQMCI). }\end{array}$ \\
\hline Component 3 & 6 & $\begin{array}{l}\text { IHC1 } \\
\text { IHC2 } \\
\text { IHC3 } \\
\text { IHC4 } \\
\text { IHC5 } \\
\text { IHC6 }\end{array}$ & $\begin{array}{l}\text { Component } 3 \text { refers to the quality of business } \\
\text { human resources (including knowledge, skills, } \\
\text { expertise, and adaptability). This component is } \\
\text { renamed "internal human resources" (IHC). }\end{array}$ \\
\hline Component 4 & 4 & $\begin{array}{l}\text { TQMCF1 } \\
\text { TQMCF2 } \\
\text { TQMCF3 } \\
\text { TQMCF4 }\end{array}$ & $\begin{array}{l}\text { Component } 4 \text { defines the organization's vision } \\
\text { which focuses on customers by understanding } \\
\text { their demand to accordingly develop and } \\
\text { introduce new suitable products. This } \\
\text { component is renamed "customer focus" } \\
\text { (TQMCF). }\end{array}$ \\
\hline Component 5 & 3 & $\begin{array}{l}\text { ACKA1 } \\
\text { ACKA2 } \\
\text { ACKA3 }\end{array}$ & $\begin{array}{l}\text { Component } 5 \text { refers to the knowledge } \\
\text { acquisition phase, which is implemented by } \\
\text { searching, following up, and exploiting } \\
\text { information from external resources. This } \\
\text { component is renamed "knowledge } \\
\text { acquisition" (ACKA) }\end{array}$ \\
\hline Component 6 & 3 & $\begin{array}{l}\text { ACKD1 } \\
\text { ACKD2 } \\
\text { ACKD3 }\end{array}$ & $\begin{array}{l}\text { Component } 6 \text { describes the ways to convert the } \\
\text { collected knowledge and use them in internal } \\
\text { business for innovation activities. This } \\
\text { component is renamed "knowledge } \\
\text { dissemination" (ACKD). }\end{array}$ \\
\hline Component 7 & 3 & $\begin{array}{l}\text { GS1 } \\
\text { GS2 } \\
\text { GS3 }\end{array}$ & $\begin{array}{l}\text { Component } 7 \text { refers to support given by the } \\
\text { government through R\&D projects, incentive } \\
\text { loans, and training programs for human } \\
\text { resources. This component is renamed } \\
\text { "government support" (GS). }\end{array}$ \\
\hline
\end{tabular}




\begin{tabular}{|c|c|c|c|}
\hline Component & $\begin{array}{c}\text { Number of } \\
\text { observable } \\
\text { variables }\end{array}$ & $\begin{array}{c}\text { Observable } \\
\text { variables }\end{array}$ & Content value \\
\hline Component 8 & 3 & $\begin{array}{l}\text { OLLC5 } \\
\text { OLLS1 } \\
\text { OLLS2 }\end{array}$ & $\begin{array}{l}\text { Component } 8 \text { is associated with learning } \\
\text { strategy, including learning policy and } \\
\text { learning mechanism to promote learning } \\
\text { capacity. This strategy sets up clear objectives } \\
\text { based on trust, sharing, and cooperation } \\
\text { between members within an organization. This } \\
\text { component is renamed "learning strategy" } \\
\text { (OLLS). }\end{array}$ \\
\hline Component 9 & 2 & $\begin{array}{l}\mathrm{CN} 2 \\
\mathrm{CN} 4\end{array}$ & $\begin{array}{l}\text { Component } 9 \text { is characterized as the } \\
\text { international collaboration among universities, } \\
\text { research institutions, and businesses. This } \\
\text { component is renamed "collaboration } \\
\text { network" }(\mathrm{CN}) \text {. }\end{array}$ \\
\hline Component 10 & 2 & $\begin{array}{l}\text { OLLC3 } \\
\text { OLLC4 }\end{array}$ & $\begin{array}{l}\text { Component } 10 \text { involves the learning culture of } \\
\text { an organization. This component is renamed } \\
\text { "learning culture" (OLLC). }\end{array}$ \\
\hline
\end{tabular}

\subsubsection{Testing scales by CFA}

Confirmatory factor analysis (CFA) is simply crucial in official research. The CFA results demonstrate that the model fits market data; in other words, the scales achieve unidimesionality (Chi-square = 1317.108, $\mathrm{df}=745, \mathrm{P}=0.000$, Chi-square/df $=1.768(\leq 2$, in any case possibly $\leq 3)$ (Carmines \& McIver, 1981) (GFI $=0.858$, $\mathrm{TLI}=0.901, \mathrm{CFI}=0.910>0.9$, RMSEA $=$ $0.045)$ (RMSEA $\leq 0.08$, but in the case of
RMSEA $\leq 0.05$, it is still very good) (Steiger, 1990).

The standardized regression weights $(\lambda)$ are greater than 0.5 , and are statistically significant ( $p=0.000<0.05)$, so the scales achieve convergent validity.

The reliability of the scales through the composite reliability $\left(\mathrm{p}_{\mathrm{c}} \geq 0.5\right)$, the variance extracted $\left(p_{v c} \geq 0.5\right)$, and Cronbach's alpha coefficient $(\geq 0.6)$ are presented in Table 4 . 


\section{Table 4}

Results of testing reliability of the scales

\begin{tabular}{lccc}
\hline Component & Composite reliability $\left(\mathrm{p}_{\mathrm{c}}\right)$ & Variance extracted $\left(\mathrm{p}_{\mathrm{vc}}\right)$ & Cronbach's alpha \\
\hline TQMTM & 0.886 & 0.570 & 0.885 \\
TQMCI & 0.900 & 0.698 & 0.898 \\
TQMCF & 0.810 & 0.519 & 0.768 \\
IHC & 0.862 & 0.515 & 0.811 \\
ACKA & 0.775 & 0.537 & 0.764 \\
ACKD & 0.751 & 0.506 & 0.735 \\
GS & 0.751 & 0.502 & 0.689 \\
OLLS & 0.739 & 0.494 & 0.671 \\
OLLC & 0.682 & 0.519 & 0.642 \\
CN & 0.659 & 0.491 & 0.653 \\
TQM & 0.759 & 0.516 & \\
OL & 0.712 & 0.562 & \\
AC & 0.693 & 0.546 & 0.845 \\
IC & 0.876 & 0.593 & \\
\hline
\end{tabular}

Table 4 shows the composite reliability and cronbach's alpha coefficients of the research scales which satisfy sufficient conditions; however, the variance extracted of some scales are low (below 0.5). This is considered one of the limitations of this study, probably stemmed from using the scales of other studies with some adjustments to be applied to the case of Vietnam. Meanwhile, this study is almost novel in Vietnam. Although many arguments erupted during qualitative research, they cannot reflect market rules perfectly. Therefore, irrespective of these restrictions the scales are confirmed to achieve the reliability so that the remaining targets could be tested prior to SEM analysis.

The results of discriminant validity test shows that the correlation coefficient (r) estimates associated with the standard error (SE) of the pairs of scale correlations have p-value $=0.000(<0.05)$, so the scales achieve discriminant validity (Table 5). 


\section{Table 5}

Testing discriminant validity

\begin{tabular}{|c|c|c|c|c|c|c|}
\hline & & & $\mathrm{r}$ & $\begin{array}{c}\mathrm{SE}=\mathrm{SQRT}((1-\mathrm{r} 2) /(\mathrm{n}- \\
2))\end{array}$ & $\begin{array}{c}\mathrm{CR}= \\
(1-\mathrm{r}) / \mathrm{SE}\end{array}$ & $\begin{array}{c}\text { p-value }= \\
\text { TDIST(CR,n- } \\
2,2)\end{array}$ \\
\hline & & & \multicolumn{4}{|l|}{ Estimate } \\
\hline TQM & $<-->$ & $\mathrm{OL}$ & 0.649 & 0.039 & 8.97 & 0.000 \\
\hline TQM & $<-->$ & $\mathrm{AC}$ & 0.435 & 0.046 & 12.20 & 0.000 \\
\hline IHC & $<-->$ & TQM & 0.165 & 0.051 & 16.46 & 0.000 \\
\hline GS & $<-->$ & TQM & 0.13 & 0.051 & 17.06 & 0.000 \\
\hline $\mathrm{CN}$ & $<-->$ & TQM & 0.406 & 0.047 & 12.64 & 0.000 \\
\hline $\mathrm{OL}$ & $<-->$ & $\mathrm{AC}$ & 0.242 & 0.050 & 15.19 & 0.000 \\
\hline IHC & $<-->$ & $\mathrm{OL}$ & 0.239 & 0.050 & 15.24 & 0.000 \\
\hline GS & $<-->$ & OL & 0.273 & 0.049 & 14.69 & 0.000 \\
\hline $\mathrm{CN}$ & $<-->$ & OL & 0.402 & 0.047 & 12.70 & 0.000 \\
\hline IHC & $<-->$ & $\mathrm{AC}$ & 0.056 & 0.051 & 18.53 & 0.000 \\
\hline GS & $<-->$ & $\mathrm{AC}$ & 0.156 & 0.051 & 16.61 & 0.000 \\
\hline $\mathrm{CN}$ & $<-->$ & $\mathrm{AC}$ & 0.058 & 0.051 & 18.35 & 0.000 \\
\hline IHC & $<-->$ & GS & 0.283 & 0.049 & 14.53 & 0.000 \\
\hline IHC & $<-->$ & $\mathrm{CN}$ & 0.135 & 0.051 & 16.97 & 0.000 \\
\hline GS & $<-->$ & $\mathrm{CN}$ & 0.309 & 0.049 & 14.13 & 0.000 \\
\hline IC & $<-->$ & TQM & 0.454 & 0.046 & 11.91 & 0.000 \\
\hline IC & $<-->$ & $\mathrm{OL}$ & 0.293 & 0.049 & 14.38 & 0.000 \\
\hline IC & $<-->$ & $\mathrm{AC}$ & 0.279 & 0.049 & 14.60 & 0.000 \\
\hline IHC & $<-->$ & IC & 0.24 & 0.050 & 15.22 & 0.000 \\
\hline $\mathrm{CN}$ & $<-->$ & IC & 0.489 & 0.045 & 11.39 & 0.000 \\
\hline GS & $<-->$ & $\mathrm{IC}$ & 0.148 & 0.051 & 16.75 & 0.000 \\
\hline e6 & $<-->$ & e5 & 0.262 & 0.050 & 14.87 & 0.000 \\
\hline e14 & $<-->$ & e12 & -0.822 & 0.029 & 62.20 & 0.000 \\
\hline e28 & $<-->$ & e34 & 0.262 & 0.050 & 14.87 & 0.000 \\
\hline
\end{tabular}




\begin{tabular}{|c|c|c|c|c|c|c|}
\hline & & & $\mathrm{r}$ & $\begin{array}{c}\mathrm{SE}=\mathrm{SQRT}((1-\mathrm{r} 2) /(\mathrm{n}- \\
2))\end{array}$ & $\begin{array}{c}\mathrm{CR}= \\
(1-\mathrm{r}) / \mathrm{SE}\end{array}$ & $\begin{array}{c}\text { p-value }= \\
\text { TDIST(CR,n- } \\
2,2)\end{array}$ \\
\hline & & & \multicolumn{4}{|l|}{ Estimate } \\
\hline e31 & $<-->$ & e26 & 0.253 & 0.050 & 15.01 & 0.000 \\
\hline e30 & $<-->$ & e36 & 0.266 & 0.050 & 14.80 & 0.000 \\
\hline e9 & $<-->$ & $\mathrm{e} 12$ & -0.348 & 0.048 & 27.96 & 0.000 \\
\hline
\end{tabular}

In brief, all scales achieve theoretical basis and qualitative research: unidimesionality, composite reliability, The model has Chi-square $=1460.107$, df variance extracted (some scales accepted), $=751(\mathrm{P}=0.000)$, Chi-square $/ \mathrm{df}=1.944$ expected cronbach's alpha coefficients, (according to Carmines and McIver (1981), convergent validity, and discriminant in some cases CMIN/df can be $\leq 3)$, RMSEA validity. $=0.050, \mathrm{CFI}=0.901>0.9$, and $\mathrm{TLI}=0.898$ $<0.9$, which does not satisfy conditions.

4.2. Testing research model and hypotheses

\subsubsection{Testing research model}

Structural Equation Modeling (SEM) is a final analysis technique employed in this paper to test the relationships between factors. The research model has seven concepts and six hypotheses. These According to unstandardized regression weights (Table 6), there are three relationships that are statistically significant ( $p$-values $>0.1$ ), namely the relationships that government support (GS), organizational learning (OL), and total quality management (TQM) have with innovation capacity (IC). assumptions are developed based on the

\section{Table 6}

Relationships between concepts in the research model

\begin{tabular}{lllccccc}
\hline & \multicolumn{2}{c}{ Relationship } & Estimate & S.E. & C.R. & P & Label \\
\hline IC & $<---$ & TQM & 10.720 & 7.842 & 1.366 & .122 & par_35 \\
IC & $<---$ & OL & -5.065 & 9.204 & -.551 & .382 & par_36 \\
IC & $<---$ & AC & 22.453 & 11.525 & 1.948 & .052 & par_37 \\
IC & $<---$ & IHC & 7.505 & 2.758 & 2.721 & .006 & par_38 \\
IC & $<---$ & CN & 8.971 & 1.805 & 4.969 & $* * *$ & par_39 \\
IC & $<---$ & GS & 12.180 & 8.316 & 1.464 & .143 & par_40 \\
\hline
\end{tabular}


For improving these research model's indicators, many different techniques are used, including analysis of covariances, or the concepts which are not statistically significant are removed from the research model. After considering and testing the model, we decide to reject OL because it has the largest $p$-value $(=0.382)$. The final results of SEM analysis are as follows:

First, Chi-square $=952.008, \mathrm{df}=480(\mathrm{P}=$ 0.000 ), Chi-square / $\mathrm{df}=1.932$ (according to Carmines \& McIver (1981), in some cases $\mathrm{CMIN} / \mathrm{df}$ can be $\leq 3)$, RMSEA $=0.048$, TLI $=0.903$, and $\mathrm{CFI}=0.912>0.9$ indicate that the model fits the market data.

In addition, the regression weights have demonstrated the relationships that the concepts of total quality management (TQM), internal human resources (IHC), absorptive capacity (AC), collaboration network (CN), and government support (GS) have with innovation capacity (IC) because of $\mathrm{p}$-value $<0.1$ and statistical significance at $90 \%$ level of reliability. The regression weights marked + confirmed that TQM, IHC, AC, CN, and GS impact positively on innovation capacity (Table 7).

\section{Table 7}

Relationships between concepts in the research model

\begin{tabular}{lllllllc}
\hline \multirow{2}{*}{ Relationship } & \multicolumn{5}{c}{ Unstandardized regression weights } & $\begin{array}{c}\text { Standardized } \\
\text { regression weights }\end{array}$ \\
\cline { 3 - 7 } & & Estimate & S.E. & C.R. & P & Label & Estimate \\
\hline IC $<---$ & TQM & 14.205 & 6.014 & 2.370 & .018 & par_31 & .276 \\
IC $<---$ & AC & 18.276 & 9.216 & 1.983 & .059 & par_32 & .107 \\
IC $<---$ & IHC & 5.744 & 2.491 & 2.305 & .025 & par_33 & .234 \\
IC $<---$ & CN & 7.825 & 1.678 & 4.654 & $* * *$ & par_34 & .395 \\
IC $<---$ & GS & 15.329 & 8.257 & 1.856 & .036 & par_35 & .172 \\
\hline
\end{tabular}

The standardized regression weights are positive, showing different degrees of impacts (Table 7), and particularly, collaboration network $(\mathrm{CN})$ strongly affects innovation capacity because the absolute value of the standardized weight is the highest (0.395). The second most important factor is total quality management (TQM), which has the standardized weight of 0.276 , followed by internal human resources (IHC) and government support (GS), whose standardized weights are 0.234 and 0.172 respectively. The lowest standardized weight $(0.107)$ is reflected by absorptive capacity (AC).

As the five concepts of TQM, AC, IHC, $\mathrm{GS}$, and $\mathrm{CN}$ only explain $51.5 \%$ of the variance of innovation capacity and this is a 
novel study on innovation capacity of enterprises in the high-tech industries in Vietnam's southern region, it can be admitted that not too much expectation is held for this value. Future research will explore and explain it better.

\subsubsection{Testing research hypotheses}

As indicated in the previous section, six hypotheses have been formulated on the relationships between the concepts. The SEM results verify these relationships as follows:

H1: Total quality management positvely affects the innovation capacity of businesses in Vietnamese southern high-tech industries.

The testing results show $\mathrm{p}$-value $=0.018$ $<0.1$, achieving statistical significance at $90 \%$ level of reliability (Table 7 ). Thus, the hypothesis H1 is accepted.

H2: Organizational learning positively affects the innovation capacity of businesses in Vietnamese southern high-tech industries (+).

The results do not verify statistical significance with $\mathrm{p}$-value $=0.382>0.1$, at $90 \%$ level of reliability. Hence, the hypothesis $\mathrm{H} 2$ is not accepted.

H3: Government support positively affects the innovation capacity of businesses in Vietnamese southern high-tech industries (+).

The study results clearly reflects reality when government support has p-value = $0.036<0.1$, statistically significant at $90 \%$ level (Table 7), and the standardized regression weight in relationship to innovation capacity reaches 0.172 . Therefore, the hypothesis H3 is accepted.
H4: Collaboration network positively affects the innovation capacity of businesses in Vietnamese southern high-tech industries (+).

The testing results indicate $\mathrm{p}$-value $=* * *$ $<0.001$ with statistical significance at $90 \%$ level of reliability (Table 7). Thus, the hypothesis H4 is accepted. The standardized regression weight of this relationship is 0.395, which asserts the importance of international collaboration network in businesses' perception.

H5: Absorptive capacity positively affects the innovation capacity of businesses in Vietnamese southern high-tech industries (+).

The hypothesis H5 is accepted due to pvalue $=0.059<0.1$ and statistical significance at $90 \%$ level of reliability. The standardized regression weight of this relationship is 0.107 (Table 7).

H6: Internal human resources positively affect the innovation capacity of businesses in Vietnamese southern high-tech industries (+).

According to the testing results, $\mathrm{p}$-value $=0.025<0.1$ at $90 \%$ level of significance (Table 7) suggests that the hypothesis H6 is accepted.

\section{Conclusion, proposed solution, research limitation}

\subsection{Conclusion}

This study seeks to determine the role of TQM, internal human resources, absorptive capacity, government support, collaboration network, and organizational learning in 
enhancing innovation capacity of businesses in Vietnamese southern high-tech industries. However, fundamentally and significantly explored are the relationships that total quality management (TQM), collaboration network (CN), absorptive capacity (AC), internal human resources (IHC), and government support (GS) have with innovation capacity (IC).

This means that TQM principles contribute firms' improved innovation capacity. It also reinforces the assertion from the previous empirical studies (Bolwijn \& Kumpe, 1990; Hamel \& Prahalad, 1994; Martinez-Costa \& Jimenez Jimenez, 2008; McAdam \& Armstrong, 2001; Prajogo \& Sohal, 2003; Mahesh, 1993; Dean \& Evans, 1994; Kanji, 1996; Tang, 1998; Roffe, 1999). Therefore, one of the key solutions to stimulate innovation capacity is to enhance the positive effects of TQM principles. In this study these principles comprise top management support (TQMTM), customer focus (TQMCF), and continuous improvement (TQMCI).

The high-tech sector is one of the main fields, so government support sources are considered to be crucial for promoting innovation activities, such as subsidies, tax incentives, or R\&D resources, especially when Vietnam integrates into the world economy as well as facing fierce competition from the external environment, or even in the domestic market, where local high-tech enterprises are also competed by the strong growth of joint venture or FDI businesses.

The study also confirms the role of absorptive capacity. It is a resource for developing the economy and implementing business innovation. Therefore, innovation capacity can be boosted through this factor by facilitating knowledge exchange and sharing or analysis of information in the form of knowledge, experience, and others at all levels of the business.

Moreover, the relationship between internal human resources and innovation capacity is proved, and this exploration confirms our expectations. Thus, if businesses are to improve innovation capability, high quality human resources is such an indispensable solution.

The study results also emphasize the positive linkage between collaboration network and innovation capacity. It can be argued that Vietnam's high-tech businesses are continuously acquiring new knowledge to promote innovation capacity, while domestic relationships are not stable enough to set up a knowledge network or to exploit or take advantage of capacity mutually. In this circumstance, the international cooperation is indeed a substantial landmark in formatting innovation. One of the essential measures, therefore, is to enhance international collaboration network, attaching especially to international businesses.

\subsection{Proposed solutions}

Schemes on developing human resources for high-tech industries underline major importance to promote innovation capacity, which focuses on building synchronous and long-term strategies for developing hightech human resources. From the forecast of 
key technology sectors, emphasis shall be laid on training criteria to ensure both "quality" and "quantity," closely tied to practical needs and in accordance with firms' recruitment criteria. These should also restrict the excess of labor force quantity and the scarcity of one's quality.

To strengthen the international cooperation network, enterprises must clearly define the major role of international cooperation in scientific research by devising long-term plans and specific solutions, exploring opportunities from international integration and actively seeking, or participating in, projects in the same field. Moreover, there is a harmony of interests for the parties involved to promote practical, efficient, and sustainable cooperation.

To successfully apply TQM, first, businesses need to change traditional governance thinking. TQM is a process to improve the quality, related to not only technology but also operating skills to adapt to environmental changes and responsibility for quality that primarily depends on the competence of managers. For this reason, the propaganda and training need to target and deploy all members of the organization.

Furthermore, it is also imperative to enhance the government's role in innovation activities, put high-tech enterprises in the center of the national innovation system (NIS), in which the government provides orientation to long-term economic and social development. The government needs to shortly complete the legal basis for the fields of science and technology and innovation, enabling businesses to access
R\&D projects and formulating favorable policies on investment and technological advances. The government should also attract foreign investments to obtain a high knowledge content.

The final recommendation is concerned with absorptive capacity. Improving human resources requires that business managers facilitate recruitments of experts to give instruction in technology transfer. Work environment needs to be established fostering exchange and sharing of information, or promoting teamwork and continuous learning.

\subsection{Research limitations}

The research model are inherited and developed from the emperical studies in the world. At present, almost no academic investigations into innovation capacity have been conducted in Vietnam, so the study scales are not perfect and the qualitative method fails to exploit different aspects of the employed concepts insightfully (observable variables).

The data are typical (sample size $\mathrm{n}=$ 380), and the cross-section depends on variation of high-tech sectors; thus, the results are only a snapshot of a dynamic phenomenon. In fact, we did realize this restriction at the initial phase, and adjust the sample size as well as limiting the research scope in several key areas, However, due to the nature of Vietnam's high-tech industries, which is quite complex and not obviously separated, the businesses considered "high technology" only account for one third of the total number in the list, derived from 
existing data sources

\section{References}

Alpkan, L., Bulut, C., Gunday, G., Ulusoy, G., \& Kilic, K. (2010). Organizational support for intrapreneurship and its interaction with human capital to enhance innovative performance. Management Decision, 48(5), 732-755.

Almus, M., \& Czarnitzki, D. (2003). The effects of public R\&D subsidies on firms' innovation activities: The case of Eastern Germany. Journal of Business and Economic Statistics, 21, 226236.

Anker, L. V. (2006). Absorptive capacity and innovative performance: A human capital approach. Economics of Innovation and New Technology, 15(4-5), 507-517.

Argyris, C., \& Schon, D. A. (1978). Organizational learning: A theory of action perspective. Addison-Wesley, MA.

Armbruster, H., Bikfalvi, A., Kinkel, S., \& Lay, G. (2008). Organizational innovation: The challenge of measuring non-technical innovation in large-scale surveys. Technovation, 28(10), 644-657.

Azevedo, F. (2007). An attempt to dynamically break symmetries in the social golfers problem. In Azevedo et al. (Eds.), Recent advances in constraints (pp. 33-47). LNAI 4651, Springer.

Bantel, K. A., \& Jackson, S. E. (1989). Top management and innovations in banking: Does the composition of the top team make a difference? Strategic Management Journal, 10(1), 107-124.

Barrow, J. W. (1993). Does total quality management equal organizational learning? Quality Progress, 26(7), 39-43.

Baum, J. A. C., Calabrese, T., \& Silverman, B. S. (2000). Don't go it alone: alliance network composition and startup's performance in Canadian biotechnology. Strategic Management Journal, 21, 267-294.

Belussi, F., Sammarra, A., \& Sedita, S. R. (2010). Learning at the boundaries in an "open regional innovation system': A focus on firms' innovation strategies in the Emilia Romagna life science industry. Research Policy, 39, 710-721.

Beugelsdijk, S., \& Cornet, M. (2002). A far friend is worth more than a good neighbor: Proximity and innovation in a small country. Journal of Management and Governance, 6, 169-188.

Block, F., \& Keller, M. R. (2008). Where do innovations come from? Transformations in the U.S. National Innovation System, 1970-2006. Report by the Information Technology and Innovation Foundation.

Bontis, N., Crossan, M., \& Hulland, J. (2002). Managing an organizational learning system by aligning stocks and flows. Journal of Management Studies, 39(4), 437-469.

Bolwijn, P. T., \& Kumpe, T. (1990). Manufacturing in the 1990s: Productivity, flexibility and innovation. Long Range Planning, 23(4), 44-57.

Bransetter, L. G., \& Sakakibara, M. (2002). When do research consortia work well and why? Evidence from Japanese panel data. American Economic Review, 92, 143-159.

Chen, H., \& Taylor, R. (2009). Exploring the impact of lean management on innovation capability. 
PICMET 2009 Proceedings August 2-6. Portland, OR.

Conner, K., \& Prahalad, C. K. (1996). A resource-based theory of the firm: Knowledge versus opportunism. Organization Science, 7(5), 477-501.

Cohen, W. M., \& Levinthal, D. A. (1990). Absorptive capacity: A new perspective on learning and innovation. Administrative Science Quarterly, 35(1), 128-152.

Czarnitzki, D., Ebersberger, B., \& Fier, A. (2007). The relationship between R\&D collaboration, subsidies and R\&D performance: Empirical evidence from Finland and Germany. Journal of Applied Econometrics, 22, 1347-1366.

Dakhli, M., \& de Clercq, D. (2004). Human capital, social capital and innovation: A multi-country study. Entrepreneurship and Regional Development, 16, 107-128.

Davenport, T. H., \& Prusak, L. (1998). Working knowledge: How organizations manage what they know. Harvard Business School Press, Boston.

Dean, J. W., \& Evans, J. R. (1994). Total quality management, organization, and strategy. West Publishing Company, Minneapolis/St Paul.

Dieu Minh. (2010). Necessity of formulating policies on technology innovation for industry sector enterprises (in Vietnamese). Science \& Technology Policy Research, 17, 61-72.

Dosi, G. (1988). Sources, procedure, and microeconomic effects of innovation. Journal of Economic Literature, 24, 1120-1171.

Egan, T. M., Yang, B., \& Bartlett, K. (2004). The effects of learning culture and job satisfaction on motivation to transfer learning and intention to turnover. Human Resource Development Quarterly, 15(3), 279-301.

Ellinger, A. D., Ellinger, A. E., Yang, B., \& Howto, S. W. (2002). The relationship between the learning organization concept and firms' financial performance: An empirical assessment. Human Resource Development Quarterly, 13(1), 5-21.

Feldman, M. P., \& Kelley, M. R. (2006). The ex ante assessment of knowledge spillovers: Government R\&D policy, economic incentives and private firm behavior. Research Policy, 35, 1509-1521.

Gellynck, X., Vermeire, B., \& Viaene, J. (2007). Innovation in food firms: Contribution of regional networks within the international business context. Entrepreneurship \& Regional Development, 19(3), 209-226.

Geroski, P. A. (1994). Market structure, corporate performance and innovative activity. Clarendon Press, Oxford.

George, G., Zahra, S. A., \& Wood, D. R. (2002). The effects of business-university alliances on innovative output and financial performance: A study of publicly traded biotechnology companies. Journal of Business Venturing, 17, 577-609.

Giuliani, E., \& Bell, M. (2005). The micro-determinants of meso-level learning and innovation: Evidence from a Chilean wine cluster. Research Policy, 34(1), 47-68.

Goldman, A. (1982). Short product life cycle: Implications for marketing activities in small high tech companies. $R$ and D Management, 12(2), 9-81.

Gustafson, D. H., \& Hundt, A. S. (1995). Findings of innovation research applied to quality 
management principles for health care. Health Care Management Review, 20(2), 16-34.

Hagedoorn, J. (1993). Understanding the rationale of strategic technology partnering: Interorganizational modes of cooperation and sectoral differences. Strategic Management Journal, 14, 371-385.

Hamel, G., \& Pralahad, C. K. (1994). Competing for the future. Harvard Business School Press, Cambridge.

Hayton, J. C., \& Kelley, D. J. (2006). A competency-based framework for promoting corporate entrepreneurship. Human Resource Management, 45(3), 407-427.

Higgins, J. M. (1995). Innovation: The core competence. Planning Review, Nov/Dec, 32-35.

Hirsch-Kreinsen, H. (2008). Low-tech innovations. Industry and Innovation, 15(1), 19-43.

Hung, R. Y. Y., Lien, B. Y. H., Yang, B., Wu, C. M., \& Kuo, Y. M. (2010). Impact of TQM and organizational learning on innovation performance in the high-tech industry. International Business Review, 20, 213-225.

Jantunen, A. (2005). Knowledge-processing capabilities and innovative performance: An empirical study. European Journal of Innovation Management, 8(3), 336-349.

Juran, J. M. (1988). Juran on planning for quality. The Free Press, New York, NY.

Lawson, B., \& Samson, D. (2001). Developing innovation capability in organisations: A dynamic capabilities approach. International Journal of Innovation Management, 5(3), 377-400.

Lee, L., \& Wong, P. K. (2009). Firm' innovative performance: The mediating role of innovative collaborations. MPRA Paper No. 16193. Munich Personal RePEc Archive.

Lichtenthaler, U. (2009). Absorptive capacity, environmental turbulence, and the complementarity of organizational learning processes. Academy of Management Review, 52(4), 822-846.

Liu, X., \& Buck, T. (2007). Innovation performance and channels for international technology spillovers: Evidence from Chinese high-tech industries. Research Policy, 36, 355-366.

Nelson, R., \& Winter, S. (1982). An evolutionary theory of economic change. Harvard University Press, Cambridge, MA.

Nonaka, I., \& Takeuchi, H. (1995). The knowledge creating company. Oxford University Press, New York.

Nystrom, H. (1990). Technological and market innovation: Strategies for product and company development. John Wiley and Sons, Chichester, UK.

Kanji, G. K. (1996). Can total quality management help innovation?. Total Quality Management, $7(1), 3-9$.

Kang, K. N., \& Park, H. (2011). Influence of government R\&D support and inter-firm collaborations on innovation in Korean biotechnology SMEs. Technovation, 32, 68-78.

McAdam, R., \& Armstrong, G. (2001). A symbiosis of quality and innovation in SMEs: A multiple case study analysis. Managerial Auditing Journal, 16(7), 394-399.

MacInnis, M., \& Heslop, L. A. (1990). Marketing planning in high tech environment. Industrial Marketing Management, 19, 160-170.

Mahesh, C. (1993). Total quality management in management development. Journal of Management 
Development, 12(7), 19-31.

Mansfield, E. (1983). Technological change and market structure: An empirical study. The American Economic Review, 73(2), 205-211.

Martinez-Costa, M., \& Jimenez-Jimenez, D. (2008). Are companies that implement TQM better learning organizations? An empirical study. Total Quality Management, 19(11), 1101-1115.

Mohrman, S. A., \& Von Glinow, M. A. (1998). High technology organizations: A synthesis. In M. A. Von Glinow \& S. A. Mohrman (Eds.), Managing complexity in high technology organizations. Oxford University Press, New York.

Niosi, J., Saviotti, P., Bellon, B., \& Crow, M. (1993). National systems of innovation: In search of a workable concept. Technology in Society, 15.

Oerlemans, L. A. G., \& Meeus, M. T. H. (2005). Do organizational and spatial proximity impact on firm performance? Regional Studies, 39(1), 89-104.

OECD. (1997b). Oslo manual: Proposed guidelines for collecting and interpreting technological innovation data (2nd Ed.). Paris.

Papaconstantinou, G. (1997). Technology and industrial performance. The OECD Observer, 204, 610.

Park, C. (2006). Studies on value-chain based innovation system: Evidence from the intermediate goods industry in Korea (PhD Dissertation). Seoul National University, Seoul.

Petrauskaite, N. (2009). Public sector, industry and academic public networking for high technology development. Science - Future of LITHUANIA, 1(3), 51-54.

Prajogo, D. I., \& Ahmed, P. K. (2006). Relationships between innovation stimulus, innovation capacity, and innovation performance. $R \& D$ Management, 36(5), 499-515.

Prajogo, D. I., \& Sohal, A. S. (2003). The relationship between TQM practices, quality performance, and innovation performance. The International Journal of Quality \& Reliability Management, 20(8), 901-918.

Riggs, H. E. (1983). Managing high technology companies. Belmont, CA.

Ritter, T., \& Gemunden, H. G. (2003). Network competence: Its impact on innovation success and its antecedent. Journal of Business Research, 56, 745-755.

Rhodes, J., Hung, R., Lok, P., Lien, B., \& Wu, C. (2008). Factors influencing organizational knowledge transfer: Implication for corporate performance. Journal of Knowledge Management, 12(3), 84-100.

Romijn, H., \& Albaladejo, M. (2002). Determinants of innovation capability in small electronics and software firms in southeast England. Research Policy, 31, 1053-1067.

Roffe, I. (1999). Innovation and creativity in organisations: A review of the implications for training and development. Journal of European Industrial Training, 23(4-5), 224-237.

Rothaermel, F. T., \& Deeds, D. L. (2004). Exploitation alliances in biotechnology: A system of new product development. Strategic Management Journal, 25, 201-221.

Roy, S., Sivakumar, K., \& Wilkinson, I. F. (2004). Innovation generation in supply chain relationships: A conceptual model and research propositions. Journal of the Academy of 
Marketing Science, 32(1), 61-79.

Schumpeter, J. A. (1911). The theory of economic development. Duncker \& Humblot, Leipzig.

Shan, W., Walker, G., \& Kogut, B. (1994). Interfirm cooperation and start up innovation in the biotechnology industry. Strategic Management Journal, 15, 387-394.

Shanklin, W. L., \& Ryans, J. K. Jr. (1984). Marketing high technology. Lexington Books, Lexington, Mass.

Souitaris, V. (2002). Technological trajectories as moderators of firm-level determinants of innovation. Research Policy, 31, 877-898.

Suarez-Villa, L. (1990). Invention, inventive learning and innovative capacity. Behavioral Science, 35(4), 290-310.

Szeto, E. (2000). Innovation capacity: Working towards a mechanism for improving innovation within an inter-organizational network. The TQM Magazine, 12(2), 149-158.

Tang, H. K. (1998). An integrative model of innovation in organizations. Technovation, 18(5), $297-$ 309.

Tether, B. S. (2002). Who co-operates for innovation, and why? An empirical analysis. Research Policy, 31, 947-967.

Tidd, J., Bessant, J., \& Pavitt, K. (1997). Managing innovation: Integrating technological, market, and organizational change. Wiley, Chichester.

Tomlinson, P. R. (2010). Co-operative ties and innovation: Some new evidence for UK manufacturing. Research Policy, 39, 762-775.

Wang, X., Yang, B., \& McLean, G. N. (2007). Influence of demographic factors and ownership type upon organizational learning culture in Chinese enterprises. International Journal of Training and Development, 11(3), 154-165.

Wallsten, S. J. (2000). The effects of government-industry R\&D programs on private R\&D: The case of the small business innovation research program. RAND Journal of Economics, 31, 82-100.

Watkins, K. E., \& Marsick, V. J. (1993). Sculpting the learning organization: Lessons in the art and science of systemic change. Jossey-Bass, San Francisco. 